\title{
The Effect of Mixed Inoculum Addition Concentration and Fermentation Time on the Characteristics of Dry Cocoa Beans (Theobroma cacao L.)
}

\author{
Ida Bagus Wayan Gunam ${ }^{a, *}$, Andi Suryanto ${ }^{a}$, G.P. Ganda Putra ${ }^{a}$, I Wayan Kasa ${ }^{b}$, \\ I Dewa Gede Mayun Permana ${ }^{c}$, Putu Sarjana ${ }^{\mathrm{d}}$, I Wayan Wisma Pradnyana Putra ${ }^{\mathrm{a}}$, Takeshi Takama ${ }^{\mathrm{e}}$ \\ ${ }^{a}$ Department of Agroindustrial Technology, Faculty of Agricultural Technology, Udayana University, Badung 80361 Bali, Indonesia \\ ${ }^{b}$ Department of Biology, Faculty of Science, Udayana University, Bukit Jimbaran, Badung Bali, 80361 Indonesia \\ ${ }^{c}$ Department of Food Science and Technology, Faculty of Agricultural Technology, Udayana University, Badung, 80361 Bali, Indonesia \\ ${ }^{d}$ Department of Agricultural Engineering, Faculty of Agricultural Technology Udayana University, Badung, 80361 Bali, Indonesia \\ ${ }^{e}$ Sustainability and Resilience Co., Babakan, Canggu, Badung, Bali, Indonesia \\ Corresponding author: *ibwgunam@unud.ac.id
}

\begin{abstract}
The fermentation process has an important role in determining the quality of cocoa beans by forming taste, color, aroma, and appearance. The purpose of this study was to determine the effect of inoculum concentration and fermentation time on the characteristics of dry cocoa beans and determine the best conditions for both inoculum addition concentration and fermentation time to produce dry cocoa beans under Indonesian national standards. The research used completely randomized design with two factors; the first factor was the starter concentration consisting of controls $(0 \%), 0.5 \%, 1 \%, 1.5 \%$, and $2 \%$ (v/w). The second factor is the fermentation time, namely 1 day, 2 days, 3 days, 4 days, and 5 days. Treatment was repeated twice to get 50 units of the experiment. The results showed that the addition concentration of mixed inoculum (Saccharomyces cerevisiae and Lactobacillus plantarum) had a significant effect on changes in temperature and $\mathrm{pH}$ during fermentation, and it also had a significant effect on total unfermented beans. This study showed that time fermentation treatment had a very significant effect on all tests. The interaction of the two treatments had a significant effect on temperature changes during fermentation; it also significantly affected total unfermented beans. According to the Indonesian National Standard of cocoa beans, the best treatment, and the fastest fermentation time to produce the first quality standard (cut test) is a concentration of $1 \%$ mixed inoculum and fermentation in 3 days.
\end{abstract}

Keywords — Characteristics; dry cocoa beans; fermentation time; mixed inoculum; starter concentration.

Manuscript received 8 May. 2020; revised 7 Nov. 2020; accepted 20 Dec. 2020. Date of publication 28 Feb. 2021. IJASEIT is licensed under a Creative Commons Attribution-Share Alike 4.0 International License.

\section{INTRODUCTION}

Cocoa (Theobroma cacao L.) is a tropical plant that can be easily found in Indonesia. In this country, the development of cocoa production grows significantly and continually. Indonesia is currently in the second position as the biggest cocoa producer globally [1]. Based on data from the Directorate General of Estate Crops [1] the total cocoa production in Indonesia is 590,684 tons in 2017, 593,833 tons in 2018 , and 596,477 tons in 2019 , obtained from 1.658.421 ha cocoa farm in 2017, 1.678.268 ha cocoa farm in 2018, and 1.683 .868 ha in 2019. However, the quality of the cocoa produced by most Indonesian farmers is low.

The fermentation process has a significant role in determining the quality of the cocoa beans, such as enzymatic reaction forming the flavor, color, and aroma; it becomes the determining factors of good taste and appearance [2]-[4]. The fermentation will prevent mold growth and hinder the process of germination, and it will make the skin of the beans lose, and the pulp of the bean will be crushed so that it will ease the drying process [5]. In general, cocoa fermentation is carried out by the activity of microbes: yeast, lactic acid bacteria, and acetic acid bacteria [6], [7]. The cocoa pulp contains sucrose, glucose, and fructose, which are the main ingredients in traditional cocoa fermentation. Microbial succession is started by yeast until the second day, then by lactic acid bacteria until the third day, and acetic acid bacteria until the fifth day. In fermentation, ethanol, lactic acid, and acetic acid are produced [7]. 
Kresnowati and Febriami [8] stated that starter culture's addition to cocoa beans' fermentation process could improve the fermentation performance. Vuyst and Weck [9] also reported that various starter cultures had been proposed for successful fermentation, particularly microbial activities of three groups of microorganisms, namely yeasts, lactic acid bacteria (LAB), and acetic acid bacteria (AAB). The addition of $S$. cerevisiae and $L$. plantarum inoculum combination at the beginning of fermentation provides the best results because it improves the fermentation's performance through microbial population's modification, sugar reduction acceleration and primary metabolite production leading to a fermentation index of $1.38 \pm 0.07$ at the end of fermentation.

Inoculum concentration is an essential factor determining cocoa beans fermentation success using microbial inoculums [10]. Ganda-Putra and Wartini [11] used the concentration of the addition of yeast $0.5-2 \%(\mathrm{v} / \mathrm{w})$; the same thing was also done by Yanti et al. [12]. The addition of inoculum as much as $0.5 \%, 1 \%, 1.5 \%$, and $2 \%(\mathrm{w} / \mathrm{w})$ can shorten the fermentation time with the quality level under the quality requirements of SNI 2323:2008 and SNI 3749:2009 [12].

This study aimed to determine the effect of adding $S$. cerevisiae and L. plantarum inoculums to the characteristics of dry cocoa beans and determine the concentration of $S$. cerevisiae and $L$. plantarum inoculum addition to produce dry cocoa beans in accordance with the Indonesian National Standard (SNI 2323:2008 and SNI 3749:2009) [13].

\section{MATERIALS AND MethodS}

\section{A. Materials, Strains, and Culture Conditions}

The main material used in this study was the cocoa pod obtained from the community plantation in Medewi Village, Pekutatan District, Jembrana Regency, of which fruit criteria were green-yellow to yellow in color, a uniform length of $10-30 \mathrm{~cm}$, weight per seed around $3.4 \mathrm{~g}$ or equivalent to 1.02 ounces per fruit, and a uniform diameter of 7-15 cm. Pure culture of $S$. cerevisiae and L. plantarum were obtained from the Microbiology Laboratory, Faculty of Agricultural Technology, Gadjah Mada University, Yogyakarta. Media and chemicals used included: de Man Rogosa and Sharpe Broth/MRSB (Merck); Potato Dextrose Agar (PDA); Peptone (Oxoid); Potato Dextrose Broth (PDB)(Oxoid); $\mathrm{NaCl}$ (Merck); $\mathrm{HCl}$, glucose, ethanol 96\%, and distilled water. Saccharomyces cerevisiae and Lactobacillus plantarum cultures used in this study were maintained on potato dextrose broth (PDB) and de Man-Rogosa-Sharpe (MRS), respectively [14].

\section{B. Research Design}

The research used a completely randomized design (CRD) with two factors; the first factor was the starter concentration consisting five levels, namely; controls $(0 \%), 0.5 \%, 1 \%$, $1.5 \%$, and $2 \%(\mathrm{v} / \mathrm{w})$. The second factor is fermentation time, namely 1 day, 2 days, 3 days, 4 days, and 5 days. The first factor was the concentration of the addition of a combination of microbes based on the optical density value of $\mathrm{OD}_{660} 5$ in the form of cells that had been washed with saline solution $(\mathrm{NaCl} 0,85 \%)$, and the addition of $S$. cerevisiae and $L$. plantarum with (1:1) ratio. The number of treatments given to the two factors was 25 , and it was repeated twice; thus, it became 50 experimental units.

\section{Materials Preparation}

Cocoa pod used in this study was stored for $48 \mathrm{~h}$, in order to make the cocoa had a uniform maturity, then it was sprayed with $70 \%$ alcohol before being broken down using blunt objects by pounding the cocoa pods each other without damaging the cocoa seeds, then the cocoa seeds were cleaned from the placenta. After that, sorting was done to remove any attached beans and cuts caused by breaking the pod skin. The cocoa seeds were then collected in a container, and after all, seeds had been collected, they were put into each fermenter prepared. All the processes were conducted in an aseptic condition.

\section{Preparation of Microbial Culture}

Pure microbial cultures were rejuvenated to make stock and working cultures. To rejuvenated cells and make working culture, $S$. cerevisiae using PDB media and $L$. plantarum using MRS broth media. The media as much as 6 $\mathrm{mL}$ was poured down into the test tube, and it was added by $1 \mathrm{~mL}$ of pure culture. The test tubes containing media and pure culture were incubated at $37^{\circ} \mathrm{C}$, shaken for $24 \mathrm{~h}$, and then it was poured into the Erlenmeyer containing fresh media for the culture growth before being shaken for $24 \mathrm{~h}$ to multiply the cells [15], [16].

All cultures were transferred to centrifuge tubes of $14 \mathrm{~mL}$ each; then, they were centrifuged at $5000 \mathrm{rpm}$ at $4^{\circ} \mathrm{C}$ for 20 min. The supernatant was removed before being added with saline solution $(0.85 \% \mathrm{NaCl})$ for $14 \mathrm{~mL}$; then, it was shaken. The process was carried out twice. The supernatant was discarded, and the cells obtained were collected and combined to check the value of their optical density $\left(\mathrm{OD}_{660}\right)$. After the $\mathrm{OD}_{660}$ had been known, it was equated by adding saline solution to have an $\mathrm{OD}_{660}$ value of 5 , and the microbial cells were ready for use [17], [18].

\section{E. Cocoa Bean Fermentation}

The fermentation process was conducted in two ways which were fermentation without the addition of a starter (control) and the fermentation with the addition of starter, a combination of the $S$. cerevisiae and $L$. plantarum in a ratio of 1:1. The microorganisms with $\mathrm{OD}_{660}$ value of 5, added at the beginning of the fermentation of cocoa seeds or on the 0 day were $0 \%, 0.5 \%, 1 \%, 1.5 \%$, and $2 \%(\mathrm{v} / \mathrm{w})$, respectively. The cocoa beans were put into the box fermenter $(6 \mathrm{~kg}$ capacity) which had previously been sprayed with $70 \%$ alcohol to avoid contamination. The fermentation was carried out on $5 \mathrm{~kg}$ of cocoa seeds per unit in a sterile fermenter at room temperature of $\pm 33-35^{\circ} \mathrm{C}$ for 5 days, and it was stirred and sampled every day $(24 \mathrm{~h})$.

\section{F. Observed Variables}

Variables observed were unfermented beans content (Indonesian National Standard), content of beans infested by insects, germinated beans content, and moldy beans content [13], cocoa's temperature, and $\mathrm{pH}$ of the cocoa pulp during the fermentation process. The total yeast was enumerated on spread plates by using PDA at $30^{\circ} \mathrm{C}$ for 2 days. In comparison, total LAB was determined using MRS agar at 
$37^{\circ} \mathrm{C}$ for $24-48 \mathrm{~h} \mathrm{[3],} \mathrm{[8].} \mathrm{Emerging} \mathrm{colonies} \mathrm{were} \mathrm{counted}$ and survivor populations were expressed as log CFU per gram $(\log \mathrm{CFU} / \mathrm{g})$ [19].

\section{G. Statistical Analysis}

All objective data were obtained in duplicate and analyzed using analysis of variance (ANOVA), facilitated by the statistical package program SPSS version 16.0 (SPSS Inc.; Chicago, IL, USA) [20] and significant differences ( $p<$ 0.05 ) among means of the treatments, then continued using Tukey's test.

\section{RESULTS AND DISCUSSION}

\section{A. Microbiological Changes in Cocoa Beans during Fermentation}

The observed microbiological changes during cocoa beans' fermentation process were total yeast and total lactic acid bacteria (LAB). Calculation of total yeast and total lactic acid bacteria in cocoa beans had been done every day $(24 \mathrm{~h})$ for 5 days of fermentation. Total yeast and lactic acid bacteria in cocoa beans were reported on a logarithmic scale as in Fig. 1 and Fig. 2. Fig. 1 showed that the total yeast in the treatments of adding microbial starter (Saccharomyces cerevisiae and Lactobacillus plantarum in the ratio of 1:1) were $0.5,1,1.5$, and $2 \%$, which increased significantly from the beginning to the second-day fermentation, then decreased after 2 days of fermentation; whereas in control (without adding a microbial starter), it significantly increased at the beginning of day 1 fermentation, then decreased until the end of fermentation. Fig. 2 showed that the population of lactic acid bacteria in the microbial starter addition treatment of $0.5 \%, 2 \%$, and control increased significantly from the beginning to the second day of fermentation, then decreased after 2 days of fermentation, while the addition of $1 \%$ and $1.5 \%$ microbial starter increased significantly from the beginning to the $3^{\text {rd }}$ day fermentation, then decreased until the end of the fermentation. Camu et al. [21], reported that all fermentation was characterized by a high lactic acid bacteria (LAB) level from at the beginning ( $8.0 \log \mathrm{CFU} / \mathrm{g}$ ), as reflected by the number of colonies on MRS media. LAB grow during fermentation to a maximum population of $8.9 \log \mathrm{CFU} / \mathrm{g}$ after $48 \mathrm{~h}$ incubation.

The microbial starter addition consisting of $S$. cerevisiae and $L$. plantarum in cocoa fermentation caused the total yeast and lactic acid bacteria to be higher than previous studies. This study's results were like the results of previous studies that showed that yeast and lactic acid bacteria were detected during cocoa fermentation and affected the total growth of yeast and LAB [6], [10]. Yeast and LAB are one of the dominant microbes during the fermentation process of cocoa beans. It was confirmed by the presence of very high yeast and LAB populations in cocoa beans' fermentation on the $2^{\text {nd }}$ day with a concentration of $2 \%$ starter addition, as shown in Fig. 1 and Fig. 2.

Kresnowati and Febriami [8], Feng et al. [22] revealed that $S$. cerevisiae and L. plantarum play an essential role in cocoa's fermentation. $S$. cerevisiae and $L$. plantarum can produce the enzyme pectinase that is capable of hydrolyzing pectin into simple sugars, ethanol, and other organic compounds. Minifie [23] stated that pectin pulp's content is $4.1 \%$, which will later be hydrolyzed by the enzyme pectinase into organic compounds, be diffused into the bean (cotyledon), and affecting flavor, color, and aroma.

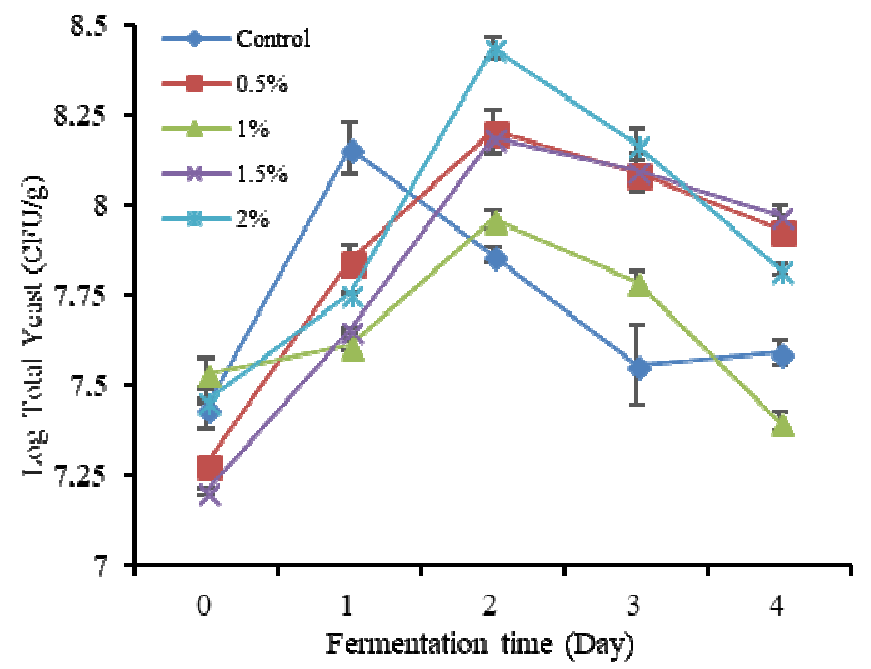

Fig. 1 Total yeast during cocoa bean fermentation

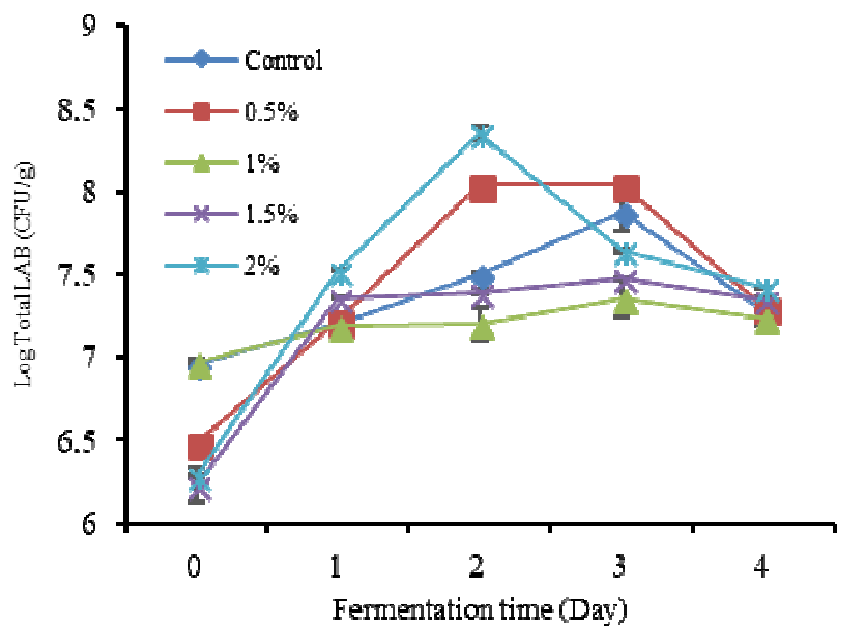

Fig. 2 Total lactic acid bacteria during fermentation of cocoa beans

Fig. 2 showed that the log total lactic acid bacteria on day 0 (starter concentration $0 \%$ or control) and $1 \%$ were the highest in the $6.98 \mathrm{log} \mathrm{CFU} / \mathrm{g}$. Meanwhile, the concentrations of $0.5 \%, 1.5 \%$, and $2 \%$ were $6.49,6.24$, and $6.28(\log \mathrm{CFU} / \mathrm{g})$, respectively. This disparity can occur due to the fermenter used in this experiment, which may have been contaminated by a few microbes previously. Fig. 1 showed the same case on the initial fermentation stages $(0$ day), the total yeast was also not uniform.

\section{B. Physical Changes in Cocoa Beans during Fermentation}

The observation of the SNI 2323:2008 cut test [13] was conducted by using the senses. The cut test was carried out by observing defective beans with the following classifications: moldy beans, unfermented beans, beans infested by insects, and germinated beans, as shown in Table 1. 
The data were taken on beans passed the drying process with a temperature of $60^{\circ} \mathrm{C}$ for $24 \mathrm{~h}$. Table 1 showed the term (D) refers to the day of fermentation (fermentation time), while the term (C) refers to the treatment (concentration of addition of starter).

1) Unfermented cocoa beans: Variance analysis results showed that the addition of microbial starter treatment had a significant effect $(p<0.05)$, and fermentation time also had a very significant effect $(p<0.01)$. Besides, the interaction between treatments had a significant effect $(p<0.05)$ on unfermented beans content (Table 2).

TABLE I

Defective Cocoa BeANS DuRING FERMENTATION

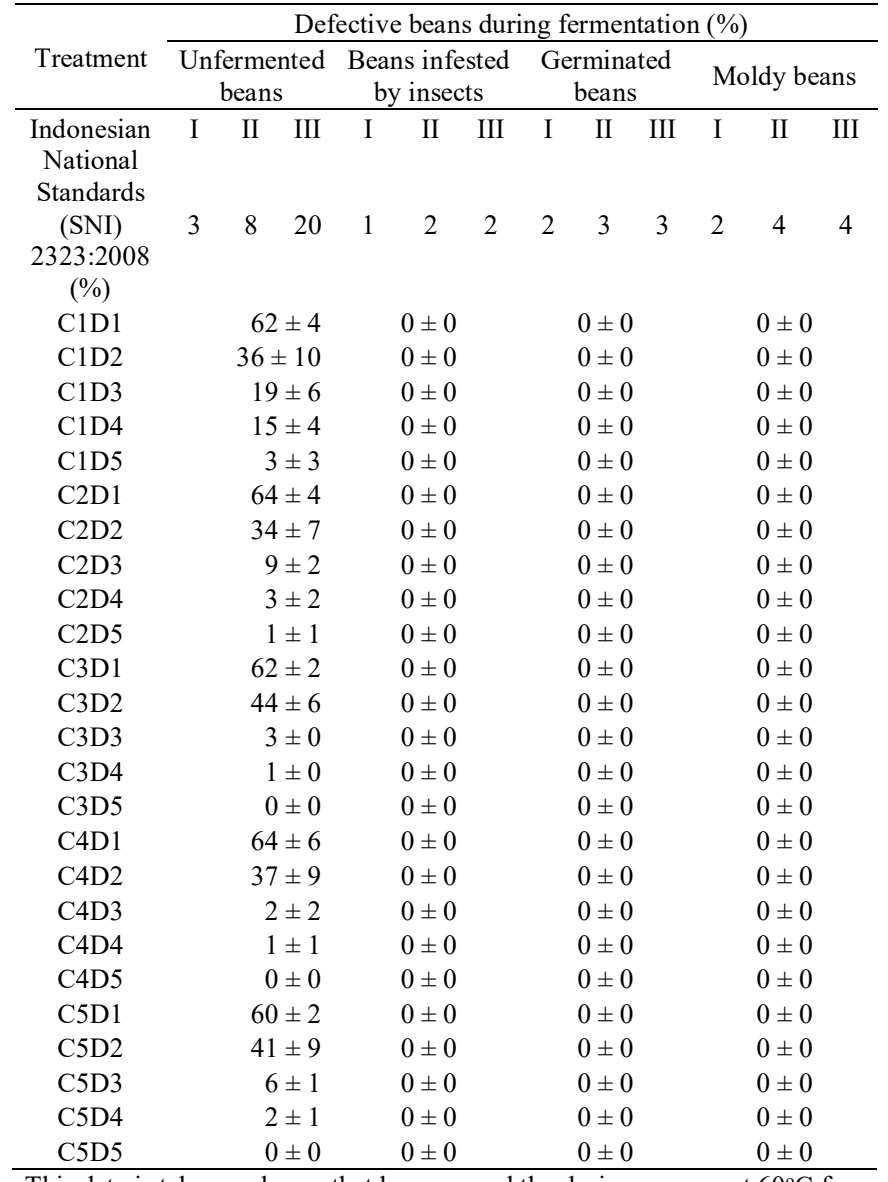

This data is taken on beans that have passed the drying process at $60^{\circ} \mathrm{C}$ for $24 \mathrm{~h}$. The term (D) refers to the time of fermentation, while the term (C) refers to the treatment of starter concentration.

The results of the determination of the total unfermented beans were categorized under the quality standard of cocoa beans stipulated in SNI 2323:2008 [13] stating that for quality of I, II, and III, the maximum numbers of unfermented cocoa beans are $3 \%, 8 \%$, and $20 \%$. The results of the unfermented beans were presented in Table 2, showing that on the $4^{\text {th }}$ day of the control treatment, the beans were fermented at the quality standard III because there were $14.5 \%$ of the beans that had not been fermented, and on the $5^{\text {th }}$ day they were fermented with the standard quality I because there were only 3\% unfermented beans found. In the treatment of adding $1 \%$ and $1.5 \%$ starter concentrations, it could be seen that the beans were fermented on the $3^{\text {rd }}$ day with the quality standard I of which percentage value of unfermented beans were $3 \%$ and $1.5 \%$, respectively. The addition of $2 \%$ concentration resulted in fermented beans with the quality standard II on the $3^{\text {rd }}$ day with a percentage value of $5.5 \%$. In the addition of a concentration of $0.5 \%$, the beans were fermented on the quality standard III on the $3^{\text {rd }}$ day with a percentage value of $8.5 \%$. On the following day, the concentrations of $2 \%$ and $0.5 \%$ were equally fermented in quality standard I with unfermented beans percentage values of $2.50 \%$ and $2.17 \%$, respectively.

Table 2 shows that the treatment of adding $1 \%$ and $1.5 \%$ microbes is the best because the beans were fermented at a quality standard I on the $3^{\text {rd }}$ day; it contradicted the previous data related to the total $\mathrm{LAB}$ showing that concentrations of $1 \%$ and $1.5 \%$ underwent slow growth, this was assumed to be due to the growth of acetic acid bacteria dominating on the second day to the end of the fermentation. It made the beans remain well-fermented because, according to Ardana and Fleet [6], Schwan and Wheal [7], the acetic acid bacteria live in cocoa fermentation and play an essential role in determining the quality of cocoa beans.

TABLE II

UNFERMENTED BEANS CONTENT (\%, BEANS/BEANS)

\begin{tabular}{cccccc}
\hline \multirow{2}{*}{$\begin{array}{c}\text { Cells } \\
\text { concentration } \\
(\%)\end{array}$} & 1 & 2 & 3 & 4 & 5 \\
\cline { 2 - 6 } & $62.17 \mathrm{a}$ & $36.00 \mathrm{c}$ & $19.00 \mathrm{de}$ & $14.50 \mathrm{ef}$ & $3.00 \mathrm{ef}$ \\
\hline 0.0 & $63.67 \mathrm{a}$ & $33.83 \mathrm{~cd}$ & $8.50 \mathrm{ef}$ & $2.50 \mathrm{ef}$ & $0.50 \mathrm{f}$ \\
0.5 & $61.67 \mathrm{a}$ & $43.83 \mathrm{bc}$ & $3.00 \mathrm{ef}$ & $1.17 \mathrm{f}$ & $0.17 \mathrm{f}$ \\
1.0 & $63.67 \mathrm{a}$ & $36.83 \mathrm{c}$ & $1.50 \mathrm{f}$ & $0.83 \mathrm{f}$ & $0.00 \mathrm{f}$ \\
1.5 & $59.67 \mathrm{ab}$ & $40.83 \mathrm{c}$ & $5.50 \mathrm{ef}$ & $2.17 \mathrm{ef}$ & $0.33 \mathrm{f}$ \\
2.0 & & \multicolumn{5}{c}{ Fermentation time (Day) } \\
\hline
\end{tabular}

The same letters behind the mean values were not significantly different in the Tukey's test of 0.05 .

According to Diansari [24], Hernández-Hernández et al. [25], during the fermentation process, cocoa beans change their color because the content of polyphenol compounds in the cotyledon oxidized by the enzyme polyphenol oxidase with the help of air, thus changing the color of the beans from purple to brown. The cotyledon that is not fully fermented indicates that they still have high levels of polyphenols; thus, they cannot produce a brown color.

2) Beans infested by insects: The results of determination of total beans infested by insects were categorized based on cocoa beans quality standard in accordance with SNI 2323:2008 [13] stating that for quality of I, II, and III the maximum amount of cocoa beans infested by the insect are 1,2, and 2. Based on Table 1, it is known that in this study, it was not found any cotyledon infested by insects in all fermentation treatments. Thus, the cocoa produced had fulfilled SNI 2323:2008. This study's results were consistent with the results of research conducted by Ariyanti [26] on the fermentation of cocoa beans in Belopa, Luwu Regency for 5-6 days, which was also found no insects during the fermentation.

The presence of insects on cocoa beans is generally caused by post-harvest handling that has not been done correctly and adequately, referring to Good Handling Practices (GHP) and Good Manufacturing Practices (GMP), as well as the presence of infestations and infections of insects and molds [27]. Insect infestation in cocoa beans causes mechanical damage or injury and holes on them so 
that the cocoa beans are broken and easily infested and infected by molds. Another thing to be aware of is insects' presence as a factor playing roles in spreading molds contamination to other healthy beans. Meanwhile, the presence of insects can be influenced by changes in chemical content in cocoa beans. Therefore, it will increase the spread of mold contaminants [27].

3) Germinated cocoa beans: The results of determination of the total germinated beans were categorized according to the quality standard of cocoa beans had fulfilled the requirements of SNI 2323:2008 stating that for the quality of I, II, and III, the maximum amount of cocoa beans germinating is 2,3 , and 3 . Based on Table 1 , it is known that in this study, all fermentation treatments contained no germination of the cotyledon. Thus, the cocoa produced had fulfilled the requirements of SNI 2323:2008. It happened because the processes of both the natural fermentation and the fermentation by the addition of a starter $(S$. cerevisiae and $L$. plantarum) could make the cotyledon die, thus fulfilling SNI 2323:2008 requirements.

According to Kustyawati and Setyani [10], the beans' death is caused by the formation of acetic acid by acetic acid bacteria diffusing into the cotyledon and the increased temperature in the fermentation substrate causing death to the beans. In other words, the fermentation process can prevent cocoa beans from germination; therefore, it will improve the quality of cocoa beans [7]. During the fermentation, most microbes can produce pectinolytic enzymes and metabolites such as organic acids that can increase acidity and reduce $\mathrm{pH}$ from 6.3 to 4 so that pectin is hydrolyzed and makes the beans of the cocoa die [22], [28].

Pereira [16] and Leal et al. [29] stated that during the process of cocoa fermentation, several enzymes are found (peroxidase, oxidase, invertase, raffinate, glycerophosphate and phytase). These enzymes cause enzymatic reactions in cocoa beans triggering changes in color, aroma, and flavor. After the cotyledons of the beans die, the process takes place while they are still in the fermenter until the drying process [30].

4) Moldy cocoa beans: The results of determination of the total moldy beans were categorized according to the quality standard of cocoa beans had fulfilled the requirements of Indonesia National Standards (SNI 2323:2008) stating that for the quality of I, II, and III, the maximum amount of moldy cocoa beans is 2,3 , and 3 . Based on Table 1, it is known that the fermentation treatment in this study freed the beans from molds, and it had fulfilled the requirements of SNI 2323:2008. It happened because the processes of both the natural fermentation and the fermentation by the addition of starter on the cocoa beans equally produced alcohol disinfectant to molds. Besides, it is known that the growth of lactic acid bacteria in the fermentation of cocoa beans can inhibit the growth of molds. This study's results were consistent with the study conducted by Suwasono and Susijahadi [31] and Ozturk and Young [32], finding several types of lactic acid bacteria from fermented cocoa beans producing antimicrobial peptide compounds that can inhibit the growth of molds growing on the cocoa beans. Hatiningsih et al. [33] also stated that the lactic acid bacterium which is $L$. fermentum isolated from the coffee beans producing anti molds metabolites against $A$. flavus FNCC 6019, A. niger FNCC 6018, and $P$. citrinum FNCC 6066.

Settanni et al. [34] stated that some strains of LAB produce lactic acid, caproic acid, acetic acid, formic acid, phenylacetic acid, and 4-hydroxy phenyl lactic acid, cyclic dipeptides such as cyclo (L-Phe-L-Pro), cyclo (Gly-L-Leu), cyclo (L-Phe-trans-4-OH-L-Pro), mevano lactone, benzoic acid, methyl hydantoin, short-chain fatty acids, protein compounds with low molecular weight (MW) and bacteriocin. The same thing was stated by Yang et al. [35] that compounds produced by lactic acid bacteria include organic acids, a peptide, diacyl, $\mathrm{CO}_{2}$, acetaldehyde, disomers, amino acids and mainly are bacteriocins that are antimicrobial and effectively inhibit microbial growth.

5) Temperature changes during fermentation: Variance analysis results showed that the addition of microbial starter treatment, fermentation time, and the interaction between treatments had very significant effects $(p<0.01)$ on the temperature changes during fermentation. The patterns of temperature changes during fermentation can be seen in Fig. 3.

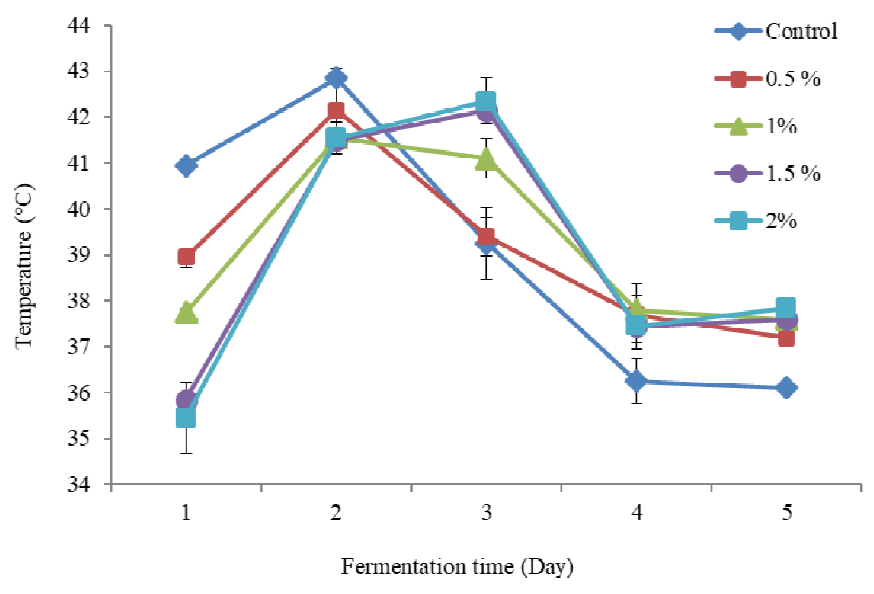

Fig. 3 Temperature changes during fermentation

The study showed that the temperature during the fermentation in the treatment of the addition of microbial starter concentrations of $1 \%, 1.5 \%$. It increased by $2 \%$ from the initial fermentation, and it was optimum on the $48^{\text {th }} \mathrm{h}$ of fermentation with temperatures of $41.92^{\circ} \mathrm{C}, 42.3^{\circ} \mathrm{C}$, and $42.83^{\circ} \mathrm{C}$. Then, it decreased until the end of the fermentation. The control treatment and $0.5 \%$ experienced an increase in temperature from the beginning to $72^{\text {th }} \mathrm{h}$ of fermentation with temperatures of $41.71^{\circ} \mathrm{C}$ and $41.85^{\circ} \mathrm{C}$. Then, it continued to decrease until the end of the fermentation. Figure 3 shows that the addition of a microbial starter makes the fermentation condition better than the control, because the addition of microbes made the temperature optimum on the $2^{\text {nd }}$ day, whereas the control treatment was optimum on the $3^{\text {rd }}$ day.

Ganeswari et al. [36] and Takrama et al. [37] stated that the temperature rise at the beginning of fermentation is influenced by converting organic sugars in cocoa pulp to alcohol by yeast, and this alcoholic fermentation process produces heat. LAB in cocoa fermentation produces lactic 
acid as the main product. Besides, it also produces acetic acid, ethanol, $\mathrm{CO}_{2}$, and causes heat release triggering the cocoa stack temperature increase. The heat makes the cocoa pulp begin to melt and make the air enter the cocoa stack cavity, causing aeration that makes conditions suitable for the dominance of acetic acid bacteria triggering optimal temperature increase in the cocoa stack. The temperature then decreases due to the heat produced in part, lost through the fermenter wall until the end of the fermentation [38].

6) $p H$ changes during fermentation: Variance analysis results showed that during the fermentation, the addition of microbial starter treatment and fermentation time had a very significant effect $(p<0.01)$ on $\mathrm{pH}$ changes, yet the interaction between treatments had no significant effect $(p>$ $0.05)$ on $\mathrm{pH}$ changes. The average $\mathrm{pH}$ changes during fermentation can be seen in Fig. 4.

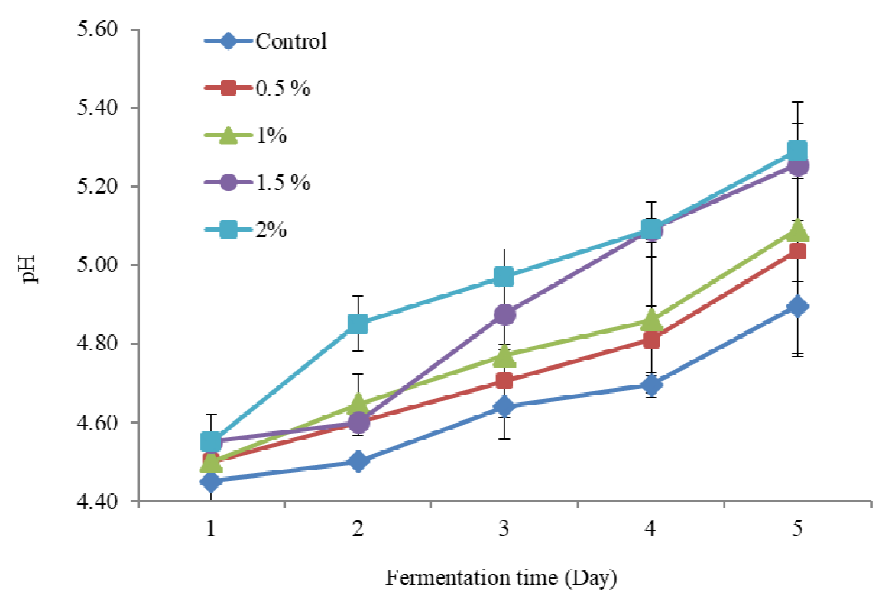

Fig. $4 \mathrm{pH}$ changes during the fermentation

Schwan and Wheals [7] stated that the initial pH of cocoa fermentation ranges from 3.5 and then rises to 4.2 on the $2^{\text {nd }}$ day of the fermentation, and it continues to increase until the end of the fermentation. Fig. 4 shows that on the $2^{\text {nd }}$ day of the fermentation, the $\mathrm{pH}$ at the control, the concentrations of $0.5 \%, 1 \%, 1.5 \%$, and $2 \%$ are $4.50,4.60,4.65,4.60$, and 4.85 , respectively. The pattern in Fig. 5 shows that this study is consistent with the previous studies, indicating that the $\mathrm{pH}$ of the pulp will tend to increase from the beginning to the end of the fermentation [24], [38].

Changes in $\mathrm{pH}$ occur due to the reaction of the breakdown of citric acid, lactic acid, and acetic acid in the cocoa pulp, the more number of acids formed by the process of sugar decomposition by yeast, the higher the $\mathrm{pH}$ value will be because the $\mathrm{pH}$ value is directly proportional to $\mathrm{H}^{+}$ concentrations obtained from weak acids in cocoa pulp [6], [10].

The concentration of the addition of mixed inoculums $(S$. cerevisiae and L. plantarum) had a very significant effect on changes in temperature and $\mathrm{pH}$ during the fermentation. It also had a significant effect on total unfermented beans, whereas the length of the fermentation treatment had a very significant effect on the content of the unfermented beans, changes in temperature, and $\mathrm{pH}$ during the fermentation. Furthermore, the two treatments' interaction had very significant effects on the temperature changes during fermentation and the total unfermented beans, but it had no significant effect on changes of $\mathrm{pH}$ during the fermentation. The best treatment to produce cocoa beans' characteristics under SNI with the fastest fermentation time was $1 \%$ concentration because the beans had been fermented on the $3^{\text {rd }}$ day by the quality standard I with a percentage value of unfermented beans of $3 \%$. Farmers easily implement a further study on making a starter in the form of yeast because its options to make a starter that must be in an aseptic condition.

7) Water content: Based on the measurement of water content in dried cocoa beans during fermentation, which was carried out under Indonesian National Standards [13], the following results were obtained.

The results of determining the water content were reported according to Fig. 5 and showing that the water content in this fermentation was under the standards because the average did not exceed the maximum standard set by the National Standardization Agency (BSN) [13] of 7.5\%. Also, cocoa beans' average moisture content was not below 5\%, which could cause the seed coat to become fragile [39], [40].

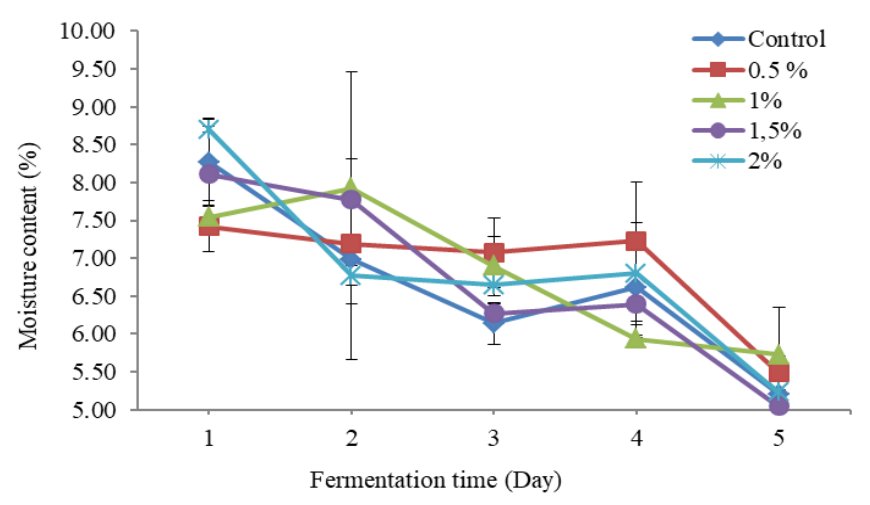

Fig. 5 Moisture content of fermented, dried cocoa beans

These results indicated that the moisture content of dried beans during fermentation gradually decreased. The average water content during fermentation from the first day to the fifth day was as follows $8.01 \% ; 7.33 \% ; 6.61 \%, 6.60 \%$, and $5.34 \%$. The decrease in water content was caused by the pulp release in the cocoa beans due to microbes' decomposition process and rinsing. Then, the drying process became more comfortable since the attached pulp did not block the beans.

According to Wollgast and Anklam [41], the decrease in water content is due to the ingredient content in beans, such as water, polyphenols, and proteins, which will break and diffuse out of seed pieces because of the generated heat from the fermentation process. This causes the weight of dried cocoa beans to decrease if the fermentation process's length.

Costa et al. [40] state that the one affecting cocoa beans' water content is the drying process. The drying process can be done naturally with sunlight and artificial drying from drying instruments (ovens). This process dries the cocoa beans from $60 \%$ water content into $6-7 \%$. At this stage, chemical changes occur to perfect the formation of good aroma and color. 


\section{Chemical Changes during Cocoa Beans Fermentation}

Chemical testing of cocoa beans was carried out after the cocoa had passed the drying process until the water content was less than $7.5 \%$ according to Indonesian National Standards [13] of cocoa beans, including water content tests fermentation index, reducing sugar content and acid content.

1) Fermentation index: During the fermentation of cocoa beans, the polyphenols in cocoa beans diffuse out, degrade, and react with other cellular compounds, causing the cocoa bean pieces to turn brown. The polyphenols in cocoa beans cause the bitter taste and cause pigment in cotyledons are whitish purple in color. The fermentation index is a measure of cocoa color changes that can be used as a success indicator of fermentation. The fermentation index values which equal to or more than 1 indicate that the bean pieces are brown and fully fermented [8]. Fermentation index, phenolic compounds, and antioxidant activity are important parameters for understanding cocoa bean quality. The following results were obtained based on the measurement of the fermentation index in dried cocoa beans during fermentation (Fig 6).

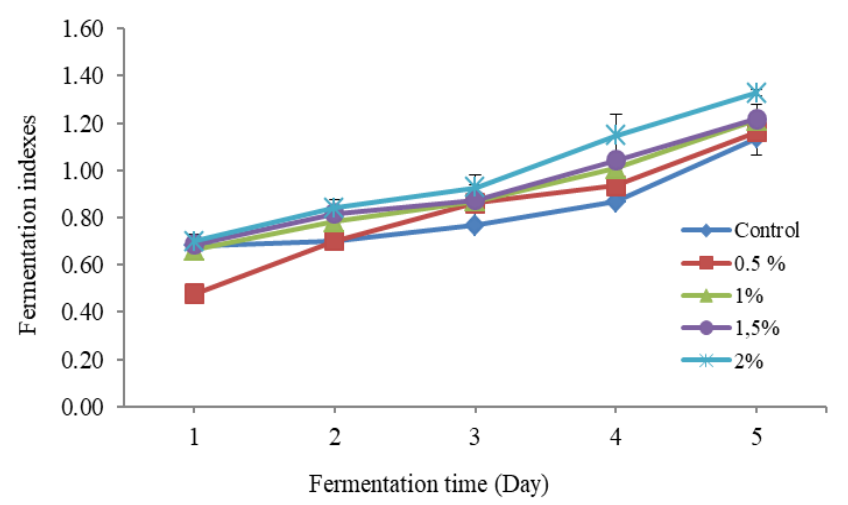

Fig. 6 Fermentation index of dried cocoa beans during fermentation

The results of determining the fermentation index are presented in Fig. 5, showing that the longer the fermentation process was, the more the value of the fermentation index would increase. It was due to the increased intensity of brown color in cocoa beans caused by the polyphenol fermentation process in the beans being oxidized by the enzyme polyphenol oxidase. According to Misnawi [42], the fermentation index value is equal to or more than 1 , which indicates that the fermentation process in cocoa beans is perfect. Then, the brown color on cocoa chips caused by complex tannins becomes dominant.

Based on Fig. 6, it showed that the natural (control) fermentation on days 1-4 beans had not been completely fermented since the fermentation index values were as follows: $0.68,0.70,0.77$, and 0.87 . Then, the natural fermentation on day 5 showed the fermentation index of 1.14 , meaning that the fermentation on day 5 was complete. A fermentation by adding a starter showed that the process occurred faster than controls. The average fermentation indexes of treatment with a starter addition were $0.63,0.79$, $0.88,1.03$, and 1.23. This data showed that on 1-2 days, the average cocoa beans had not been fully fermented, but on day 3 cocoa beans were sufficiently fermented with a fermentation index that got closer to 1 . On the other hand, the fermentation on days 4 and 5 showed that cocoa was completely fermented.

This data had a pattern in line with the previous data. The total of unfermented beans tested by the cut-test method showed that the longer the fermentation process was, the more the fermented beans would be perfect. Adding microbial starters (S. cerevisiae and $L$. plantarum) could speed up the fermentation process compared to natural fermentation (without adding the microbes). Ganda-Putra et al. [43] also stated that natural fermentation tends to be slower than the treatments, as follows:

- Optimum conditions of pulp pectin depolymerization by polygalacturonate $(\mathrm{PG})$ (temperature $47.5^{\circ} \mathrm{C}$; initial $\mathrm{pH}$ of pulp 4.6).

- Depolymerization optimum conditions under the sequence of demethylation optimum conditions of pulp pectin by endogenous pectin methyl esterase (PME).

- The depolymerization optimum condition of pulp pectin by PG (temperature $48.5^{\circ} \mathrm{C}$; initial pulp pH 8.0 for 1 day.

- Temperature $47.5^{\circ} \mathrm{C}$; initial pulp pH 4.6 for 6 days).

2) Sugar reduction total: Reducing sugar resulted from pectin, starch, and sucrose overhauls contained in the pulp by microbial during fermentation. With the help of the pectinase enzyme, pectin was broken down into alcohol and pectinid acid; then pectinid acid, with the help of the pectinase enzyme, was broken down into galactose, arabinose, and acetic acid. Starch in the placenta was converted into sugar by amylolytic yeasts. Besides reducing sugar function as raw material for ethanol formation, it also functioned as a candidate flavor compounds in cocoa beans [44]. Glucose and fructose were the main reducing sugars in cocoa beans produced by the enzymatic process of anthocyanins to produce arabinose and galactose by the glycosidase action [16], [45]. Reducing sugars were percussive aromas of carbonyl in the cocoa bean fermentation produced through sucrose hydrolysis by the glycosidase action enzyme invertase, which would later be a determining factor for the cocoa bean aroma [46].

From the presented data in Fig. 7, the total of reduced sugar in all treatments increased at the beginning of fermentation and then decreased on the $2^{\text {nd }}$ day, then tend was stable until the end of fermentation. Following previous studies conducted by Afoakwa et al. [47], the reduced sugar content in fermented cocoa beans increases at the beginning of fermentation and decreases in the middle of fermentation, and remains stable until the end of the fermentation period. Apriyanto et al. [44] stated that the sugar reduction in dry cocoa beans at the beginning of the fermentation process 4.5 \pm 0.1 increased to $11.45 \pm 0.1$ at the next $24 \mathrm{~h}$ of fermentation it continued to fall to $10.6 \pm 0.1$ in $120 \mathrm{~h}$ of fermentation.

Changes in reducing sugar concentration indicate that there are metabolic changes during fermentation [48]. When viewed from microbial succession, this data appeared to correlate with total yeast and total $\mathrm{LAB}$, which was optimal on the second day. It was supposed that these microbes caused metabolic changes to occur. Besides, this data also appeared to correlate with the fermentation index data showing that the hindering control treatment had a lower fermentation index value compared to the addition of starter 
treatment (S. cerevisiae and L. plantarum). It was suspected that there were more percentages of reducing sugar, which would cause cocoa beans to have better color and aroma.

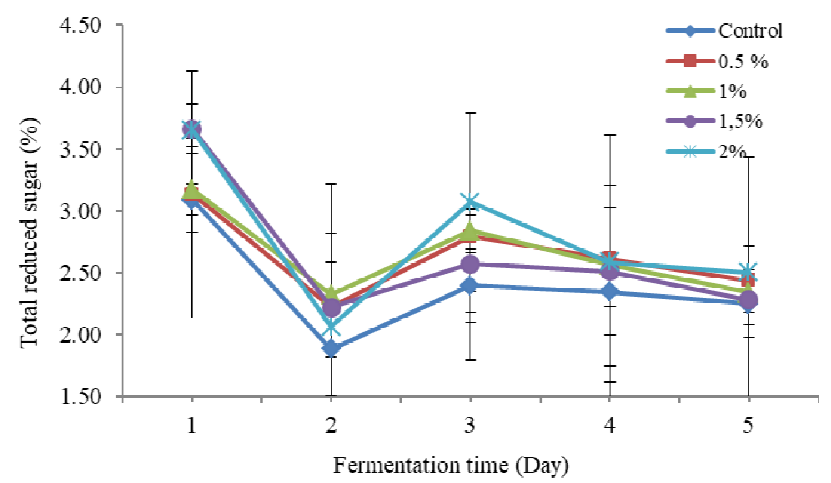

Fig. 7 Total of reduced sugar in dry cocoa beans during fermentation

3) Acid total: Based on the acid total measurement in dried cocoa beans during fermentation, the following results were obtained. The results of determining the fermentation index were reported according to Fig. 8. They showed that in the control (without adding a starter), the optimal total acid on day 3 with a value of $1.52 \%$ decreased until day 5 with a total acid value of $1.34 \%$. In the treatment of adding starters $0.5 \%, 1 \%, 1.5 \%$, and $2 \%$, the total optimal acid on the $2^{\text {nd }}$ day with a value of $2.09 \%, 1.60 \%, 1.86 \%$, and $2.01 \%$ decreased slowly until the day 5 with total acid values of $1.41 \%, 1.42 \%, 1.48 \%$, and $1.41 \%$. The treatment of adding starter (L. plantarum) at the beginning of fermentation was able to replace the role of $S$. cerevisiae, as evidenced by the increase in total acid value on the day 2 of fermentation. It was in line with previous data which stated that the total lactic acid bacteria were optimal on day 2. Apriyanto et al. [44] reported that fermented cocoa beans were added by starters ( $S$. cerevisiae, L. lactis, and A. aceti), stated that adding $L$. lactis FNCC0856 at the beginning of fermentation could immediately replace the role of $S$. cerevisiae evidenced by increasing the production of lactic acid from $1.3 \% \pm 0.1$ in $12 \mathrm{~h}$ of fermentation to $4.5 \% \pm 0.1$ in $60 \mathrm{~h}$ of fermentation. After that, it decreased to $1.8 \% \pm 0.1$ in $120 \mathrm{~h}$ of fermentation. The total acid in the pulp results from an overhaul of sugar into alcohol by $S$. cerevisiae. The glucose sugar becomes lactic acid by LAB, and alcohol becomes acetic acid by acetic acid bacteria dominated by $A$. aceti [45]. Naturally, acetic acid bacteria will remain alive in cocoa fermentation [16], [38]. At the beginning of $24 \mathrm{~h}$, the yeast fermentation dominated fermentation, which overhauled the pulp's sugar component. The treatment of adding a starter caused the acid total to increase and was optimal on the $2^{\text {nd }}$ day, while the control increased on the $2^{\text {nd }}$ day and optimal on the $3^{\text {rd }}$ day. It meant that the sugar overhaul carried out by yeast was more optimal in the starter addition treatment compared to the control. When the anaerobic phase of cocoa fermentation process begins to stop because the pulp begins to melt due to an overhaul by LAB and yeast which causes air to enter, then microbial succession will be continued by acetic acid bacteria which will convert ethanol into acetic acid [37], [42], [49], [50]. The acid content in fermented cocoa beans is the quality indication of dried cocoa beans. Schwan and Wheal [7] explained that in LAB stages producing ethanol and lactic acid, ethanol is broken down by acetic acid bacteria into acetic acid and organic acids. In the dynamics of ethanol formation, there are also the dynamics of acid formation following the same pattern. This is because the acid formed mainly comes from the oxidation of ethanol to acetic acid.

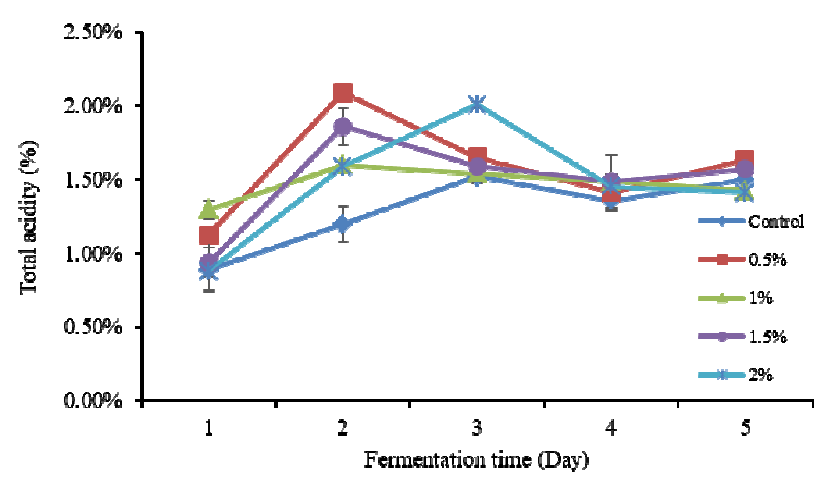

Fig. 8 Total acidity of dried cocoa beans during fermentation

\section{CONCLUSIONS}

The best treatments to produce the best cocoa beans quality characteristics and the fastest fermentation time are the microbial culture concentration of $1.0 \%$ because the beans have been fermented on the third day with the quality standard I and the percentage values of unfermented beans of $3.0 \%$.

\section{ACKNOWLEDGMENT}

The authors would like to thank the Ministry of Research, Technology, and Higher Education of the Republic of Indonesia and Udayana University for providing funding assistance and research facilities through the Higher Education Research (PUPT) grant (2016).

\section{REFERENCES}

[1] D. D. Hendaryati and Y. Ariyanto, Tree Crop Estate Statistic of Indonesia 2017-2019 Cocoa. Directorate General of Estate Crop, Ministry of Agriculture, Jakarta Indonesia, 2018.

[2] L. Maïmouna Kouamé, "Cocoa Fermentation from agnéby-tiassa: biochemical study of microflora," Am. J. Biosci., vol. 3, no. 6, pp. 203, 2015.

[3] M. T. A. P. Kresnowati, L. Suryani, and M. Affifah, "Improvement of cocoa beans fermentation by LAB starter addition," Journal of Medical and Bioengineering, vol. 2(4), pp. 274-278, 2013.

[4] V. T. T. Ho, J. Zhao, and G. Fleet, "Yeasts are essential for cocoa bean fermentation," International Journal of Food Microbiology, vol. 174, pp. 72-87, 2014.

[5] O. A. Emmanuel, Q. Jennifer, S. B. Agnes, S. T. Jemmy, K. S. Firibu, "Influence of pulp-preconditioning and fermentation on fermentative quality and appearance of Ghanaian cocoa (Theobroma cacao L.) beans," Int. Food Res. J. vol. 19, pp. 127-133, 2012.

[6] M. M. Ardhana and G. H. Fleet, "The microbial ecology of cocoa bean fermentations in Indonesia," Inter. J. Food Microbiol., vol. 86, pp. 87-99, 2003.

[7] R. F. Schwan and A. E. Wheals, "The microbiology of cocoa fermentation and its role in chocolate quality," Crit Rev Food Sci Nutr, vol. 44, pp. 205-221, 2004.

[8] M. T. A. P. Kresnowati and H. Febriami, "Mapping the effects of starter culture addition on cocoa bean fermentation," ASEAN Engineering Journal Part B., vol. 5(1), pp. 2286-7694, 2015.

[9] L. De Vuyst and S. Weckx, "The cocoa bean fermentation process: from ecosystem analysis to starter culture development, Review Article," Journal of Applied Microbiology, vol. 121, pp. 5-17, 2016.

[10] M. E. Kustyawati and S. Setyani, Effect of adding mixed inoculum on chemical and microbiological changes during chocolate 
fermentation, Jurnal Teknologi Industri dan Hasil Pertanian, vol. 13, no. 2, pp. 73-84, 2008.

[11] G. P. Ganda-Putra and N. M. Wartini, Cocoa Fermentation Design. Udayana University Press, Denpasar, 2017.

[12] N. A. Yanti, Jamili, P. E. Susilowati, Cocoa beans quality improvement through microbial fermentation process by local origin Southeast Sulawesi, Proc. The Semirata National Seminar, IPB, Bogor, 2014.

[13] BSN, Biji kakao. Badan Standardisasi Nasional, Jakarta, SNI Std. 2323:2008, pp. 1-37, 2008.

[14] M. V. S. Sandhya, B. S. Yallappa, M. C. Varadaraj, J. Puranaik, L. J. Rao, P. Janardhan, P. S. Murthy, "Inoculum of the starter consortia and interactive metabolic process in enhancing quality of cocoa bean (Theobroma cacao) fermentation," LWT-Food Science and Technology, vol. 65, pp. 731-738, 2016.

[15] L. P. T. Darmayanti, N. S. Antara, and A. S. Duniaji, Physicochemical characteristic and protein profile of fermented urutan (Balinese sausage), International Journal on Advanced Science, Engineering and Information Technology, vol. 4, no. 2, pp. 75-79, 2014.

[16] G. V. de M. Pereira, "Microbiological and Physicochemical Performance of Cocoa Bean Fermentations Carried Out in Different Systems and Screening of Yeast and Bacteria Strains Toward Development of a Starter Culture,”p. 179, 2012.

[17] V. R. Reis, A. T. B. F. Antonangelo, A. P. G. Bassi, D. Colombi, and S. R. Ceccato-Antonini, "Bioethanol strains of Saccharomyces cerevisiae characterized by microsatellite and stress resistance," Brazilian Journal of Microbiology, vol. 48, no. 2, pp. 268-274, 2017.

[18] I. B. W. Gunam, N. S. Antara, A. A. M. D. Anggreni, Y. Setiyo, I P. E. Wiguna, I M. M. Wijaya, and I W. W. P. Putra, "Chemical pretreatment of lignocellulosic wastes for cellulase production by Aspergillus niger FNU 6018," AIP Conf. Proc., 2155: 020040-1-10, 2019.

[19] A. A, Gabriel and A. S. Alano-Budiao, "Thermal inactivation of Pseudomonas aeruginosa 1244 in salted Sardinella fimbriata meat homogenate," Agr. Nat. Resour, vol. 53, pp. 79-83, 2019.

[20] SPSS, SPSS for Windows, Version 16.0. SPSS Inc. Chicago, IL, USA, 2007.

[21] N. Camu, T. D. Winter, K. Verbrugghe, I. Cleenwerck, P. Vandamme, J. S. Takrama, M. Van Canneyt, and L. De Vuyst, "Dynamics and biodiversity of populations of lactic acid bacteria and acetic acid bacteria involved in spontaneous heap fermentation of cocoa beans in Ghana," Applied and Environmental Microbiology, vol. 73, no. 6, pp. 1809-1824, 2007.

[22] X. Feng, H. Dong, P. Yang, R. Yang, J. Lu, J. Lv, J. Sheng, "Culturedependent and -independent methods to investigate the predominant microorganisms associated with wet processed coffee," Current Microbiology, vol. 73, no. 2, pp. 190-195, 2016.

[23] B. W. Minifie, Chocolate, Cocoa and Confectionary: Science and Technology. Connecticut: The AVI Publishing, 1999.

[24] A. Z. Diansari, Physical, chemical and microbiological characteristics of dry cocoa beans produced by PTPN XII). Unpublish. Faculty of Agricultural Technology, Jember University, Jember, 2015.

[25] C. Hernández-Hernández, P. A. López-Andrade, M. A. RamírezGuillermo, D. Guerra Ramírez, and J. F. Caballero Pérez, "Evaluation of different fermentation processes for use by small cocoa growers in mexico," Food Sci. Nutr., vol. 4, no. 5, pp. 690-695, 2016.

[26] M. Ariyanti, Characteristics of the quality of cocoa beans (Theobroma cacao L.) with fermentation time treatment based on: SNI 2323-2008, Jurnal Industri Hasil Perkebunan, vol. 12, no. 1, pp. 34-42, 2017.

[27] Rubiyo and W. Amaria, Resistance of cocoa to black pod disease (Phytophthora palmivora Butl.). Perspektif, vol. 12, no. 1, pp. 23-36, 2013

[28] D. M. H. Farah, A. H. Zaibunnisa, and Misnawi, "Optimization of cocoa beans roasting process using Response Surface Methodology based on concentration of pyrazine and acrylamide," International Food Research Journal, vol. 19, no. 4, pp. 1355-1359, 2012.

[29] G. A. Leal, L. H. Gomes, P. Efraim, F. C. De Almeida Tavares, and A. Figueira, "Fermentation of cacao (Theobroma cacao L.) seeds with a hybrid Kluyveromyces marxianus strain improved product quality attributes," FEMS Yeast Res., vol. 8, no. 5, pp. 788-798, 2008.

[30] T. A. Reolofsen, Fermentation, "Drying and Storage of Cocoa Beans," Advances in Food Research, vol. 8, pp. 225-296, 1958.
[31] S. Suwasono and Susijahadi, Exploration of Anti-Agents from Lactic Acid Bacteria in Cocoa Fermentation: Its Potential to Improve the Quality of Exported Cocoa Commodities, Research Report, Faculty of Agricultural Technology, Jember University, 2007.

[32] G. Ozturk and G. M. Young, "Food evolution: the impact of society and science on the fermentation of cocoa beans," Compr. Rev. Food Sci. Food Saf., vol. 16, no. 3, pp. 431-455, 2017.

[33] S. Hatiningsih, N. S. Antara, and I. B. W. Gunam, Microbiological and physicochemical changes of green coffee (Coffea arabica) fermentation in Kintamani, Bangli, Bali. Scientific Journal of Food Technology, vol. 5, no. 2, pp. 123-138, 2018.

[34] L. Settanni, O. Massitti1, D. Van Sinderen, and A. Corsetti, "In situactivity of a bacteriocin-producing Lactococcus lactisstrain. Influence on the interactions between lactic acid bacteria during sourdough fermentation," Journal of Applied Microbiology, vol. 99, pp. 670-681, 2005.

[35] E. Yang, L. Fan, Y. Jiang, C. Doucette, and S. Fillmore, "Antimicrobial activity of bacteriocin-producing lactic acid bacteria isolated from cheeses and yogurts," AMB Express, vol. 2, pp. 48, 2012.

[36] I. Ganeswari, S. Khairul Bariah, M. A. Amizi, and K. Y. Sim, "Effects of different fermentation approaches on the microbiological and physicochemical changes during cocoa bean fermentation," Int. Food Res. J., vol. 22, no. 1, pp. 70-76, 2015.

[37] J. F. Takrama, W. O. Kumi, G. Otoo, K. Addo, and N. Camu, "Optimization of cocoa pulp juice fermentation with yeast starter cultures of cocoa heap fermentations," J. Agric. Sci. Food Technol., vol. 1 , no. 3 , pp. 22-33, 2015.

[38] R. F. Schwan, "Cocoa fermentations conducted with a defined microbial cocktail inoculum," Journal Microbiology, vol. 14, pp. 1477-1483, 1998

[39] T. Wahyudi and P. Rahardjo, History and Prospects in Cocoa: Agribusiness Management from Upstream to Downstream, Complete Guidelines for Cocoa, Penebar Swadaya, Jakarta, 2009.

[40] A. Costa, C. Entzminger, A. Fredericq, M. Gilmour, R. Matissek, and S. Quintana, Cocoa Beans: Chocolate \& Cocoa Industry Quality Requirements. ECA-Caobisco-FCC Cocoa Research Fund, 2015.

[41] J. Wollgast and E. Anklam, "Review on polyphenols in Theobroma cacao: changes in composition during the manufacture of chocolate and methodology for identification and quantification," Food Research International, vol. 33, pp. 423-444, 2000.

[42] Misnawi, Physico-Chemical changes during cocoa fermentation and key enzymes involved. Review Penelitian Kopi dan Kakao, vol. 24, no. 1, pp. 47-64, 2008.

[43] G. P. Ganda-Putra, L. P. Wrasiati, and N. M. Wartini, Fermentation process of cocoa based on optimum condition of pulp pectin depolymerization by endogenous pectolityc enzymes. Pelita Perkebunan, vol. 26, no. 2, pp. 122-132, 2010.

[44] M. Apriyanto, Sutardi, E. Harmanyani, Supriyanto, Improvement of the fermentation process of non-fermented cocoa beans with the addition of pure cultures of Saccharomyces cerevisiae, Lactobacillus lactis, and Acetobacter aceti. Agritech, vol. 36, no. 4, pp. 410-415, 2016.

[45] L. De Vuyst and S. Weckx, "The Functional Role of Lactic Acid Bacteria in Cocoa Bean Fermentation," Biotechnol. Lact. Acid Bact. Nov. Appl. Second Ed., pp. 248-278, 2015.

[46] E. O. Afoakwa, J. E. Kongor, J. Takrama, and A. S. Budu, "Changes in nib acidification and biochemical composition during fermentation of pulp pre-conditioned cocoa (Theobroma cacao) beans," International Food Research Journal, vol. 20, no. 4, pp. 1843-1853, 2013a.

[47] E. O. Afoakwa, J. E. Kongor, J. F. Takrama, A. S. Budu, H. MensahBrown, "Effects of pulp preconditioning on total polyphenols, Odiphenols, and anthocyanin concentrations during fermentation and drying of cocoa (Theobroma cacao) beans," Journal of Food Science and Engineering, vol. 3, pp. 235-245, 2013b.

[48] I. M. da V. Moreira, M. G. da C. P. Miguel, W. F. Duarte, D. R. Dias, and R. F. Schwan, "Microbial succession and the dynamics of metabolites and sugars during the fermentation of three different cocoa (Theobroma cacao L.) hybrids," Food Research International, vol. 54, no. 1, pp. 9-17, 2013.

[49] A. S. Lopez and P. S. Dimick, Cocoa Fermentation. In: Emzymes, Biomass, Food and Feed, 2nd ed. Biotechnology, vol 9. Reed, G. and T.W. Nagodawithana (Eds.). VCH. Weinheim, Germany, 1995.

[50] S. T. Beckket, Industrial Chocolate Manufacture and Use. $4^{\text {th }}$, Wiley-Blackwell, United Kingdom, 2009. 